\title{
Debris flows in the central sector of the northern slopes of the Main Caucasus Ridge: peculiarities of the current situation
}

\author{
E. V. Zaporozhchenko \\ OAO Sevkavgiprovodhoz, Pyatigorsk, Russia \\ (Email:skgvh@skgvh.ru)
}

\begin{abstract}
This paper provides examples of real events of debris flows in the 21 st century. The analysis of the debris flows reveals that there is a variety of manifestation of debris flow processes and triggering factors. It also demonstrates the lack of prospects for the modern trend of creating a single model for forecasting the occurrence, development, impacts and parameters of debris flows that would be equally suitable for other phenomena of gravitational nature such as avalanches, landslides or rock falls. Moreover, it shows that the monitoring is unrepresentative, which is unacceptable, and demonstrates the often lack of hydrometeorological data on mountainous areas.
\end{abstract}

Keywords: climatic background, debris flows, sites and channels, forecasts.

Paper Received: 24 March 2015

Paper Accepted: 09 January 2016

\section{INTRODUCTION}

Since the second half of the 20th century, debris flows in mountain areas and piedmont areas of the North Caucasus have demonstrated a continued trend of increasing in number, frequency and power. Thus damage to urban sites and developed areas has also been increased. The reason for this trend is the changes in the climatic background - the decreasing of solid precipitation in winter and shortening of the winter season, increasing of liquid precipitation in spring and summer and elongation of the spring-summer period - which have led to the degradation of mountain glaciation (Zaporozhchenko 2008a).

Masses of previously frozen single-grained materials (primarily, moraine) get exposed. They deconsolidate and mature for subsequent shifting and movement along the movement paths (channels). Increasing storm rainfall in the foothills and intermontane kettles, which have previously been in "rain shadow" zones, leads to the saturation of the upper layers of the Quaternary formation. This initiates landslide and debris flow processes, including in locations, where they have not been observed, or have been rare, in the historic period (Kamenev and Zaporozhchenko 2013).

Human activities also lead to the increase of debris flow disasters. Such activities primarily have to do with the development of recreational infrastructure without considering engineering geological settings and without sufficient surveying while designing such facilities (Kazakov 2014).

The issue of short-term forecasts of debris flow processes is extremely pressing. In the last decades there have only been single known instances of reliable and, most importantly, timely forecasts of debris flow threats, which have realized in real events: the Dzhaylyk, Dhyly-Suu, Bulungu events (Zaporozhchenko 1985, Zaporozhchenko 1988)). Those successful forecasts were the result of engineering investigations of potentially hazardous debris-flows, carried out by $O A O$ Sevkavgiprovodhoz. Morphological, hydrological and engineering geological conditions in the basins and in origin areas were assessed. The transformation nature of the flows and their capabilities to reach vital facilities were evaluated.

An analysis of glaciation dynamics in western and central parts of the northern slopes of the Caucasus as of the first decade of the 21 st century confirmed the fact that had "started upon the last maximum advance of glaciers in the first half or in the middle of the 19th century", which "corresponds with the present day notion of the global glacial changes", as "in the last decades practically all glaciers on Earth have been retreating" (Bushueva 2013). The Caucasus glaciers in this period have decreased in length down to $2.5 \mathrm{~km}$ and have moved up to $1 \mathrm{~km}$ up to higher altitudes.

This can be illustrated by the example of the Terskol Glacier tongue (Prielbrusye, Kabardino-Balkar Republic). In August, 2014 a clear photograph, taken in August 1884, was found and the point from where it had been shot was located. Bushueva (2013) published another photo from Dechy's publication of 1905, where "the glacier terminus is poorly visible, so it is hard to reconstruct its location". As then the glacier floated over an almost vertical granodiorite riegel (rock-bar), whereas now it hangs over a bare wall, it is not hard to determine (Fig. 1) that for 130 years it contracted by approximately $650 \mathrm{~m}( \pm 20 \mathrm{~m})$. For glacier terminus, the reaction time to a climatic signal is on average 10-50 years (Oerlemans 2001).

A historically unprecedented situation has developed in the Caucasus Mountains whereby it favoured the entrainment by water flows of new masses of hard material of periglacial zones. The transport conditions for these masses along channels have changed (making it possible for them to reach vital facilities) as a result of increased undercutting of debris flow initiation sites, which, in turn, is connected with the climatic trend of global warming. 

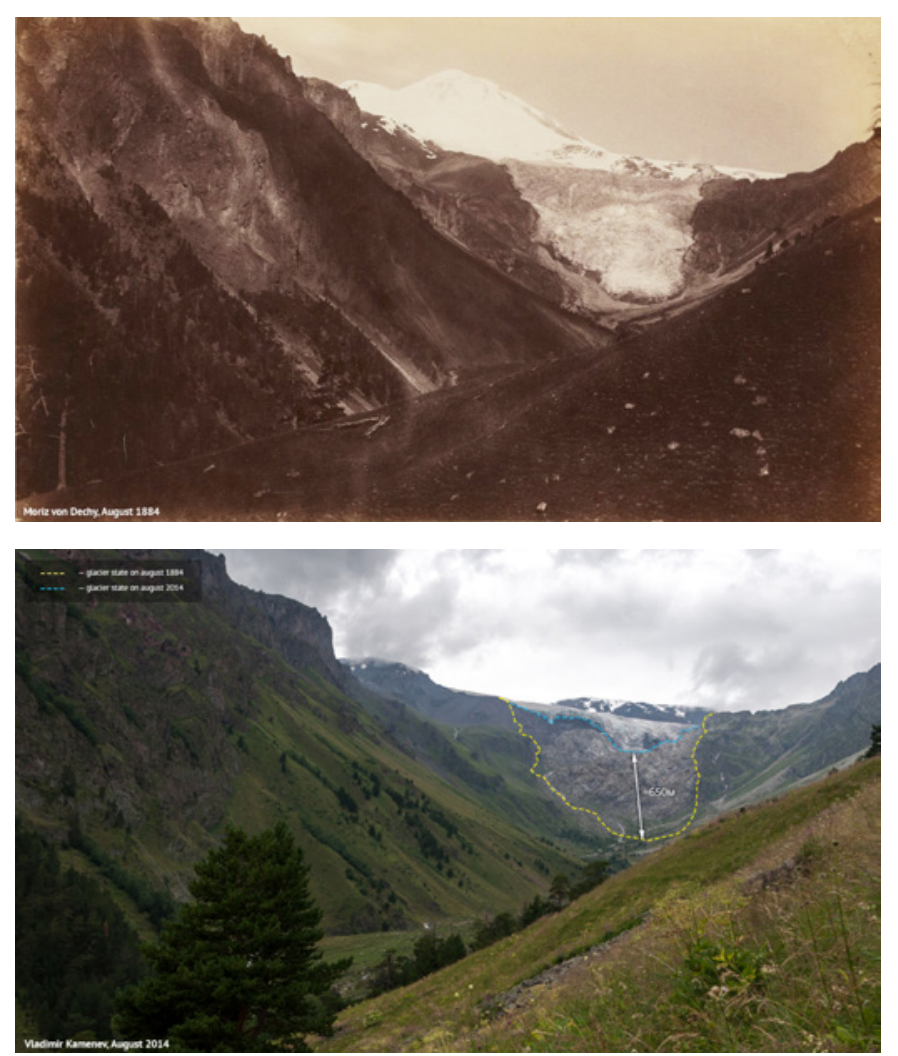

Fig 1: The Terskol glacier (Prielbrusye, Kabardino-Balkar Republic) retreated by approximately $650 \mathrm{~m}$ for 130 years. Pictures taken by M. von Dechy in August 1884 (top) and by V. Kamenev of OAO Sevkavgiprovodhoz in August 2014 (bottom).

\section{FACTUAL CHRONOLOGY OF EVENTS}

2000: A catastrophic debris flow event on the GerhozhanSuu River caused human losses (about 125 people), property destruction and flooding of a part of the town of Tyrnyauz.

Initially, a debris flow chute was designed, but its construction was stopped. Another design was approved and realized. The new structure built to this design was destroyed by the first debris flow 2 months after being put in commission.

Without getting into a detailed analysis of a number of issues arising after the debris flow on July 18-25, 2000 (Zaporozhchenko 2001), a debris flow chute was built (reconstructed) on the fan of the Gerhozhan-Suu River, which has successfully protected the town of Tyrnyauz from several debris flows of the last decade. The most recent one of August, 3, 2011, effectively passed through the chute (Fig. 2) in 4 hours, in waves, with a peak discharge of 472 cubic meters per second (instrumentally gauged).

A 60-year experience of field observations in the debris flow hazardous catchment of the Gerhozhan-Suu River shows:

all significant debris flow events of 1960 and the following years (including 2000) have been of glacial genesis and initiated in the upper reaches of the left tributary of

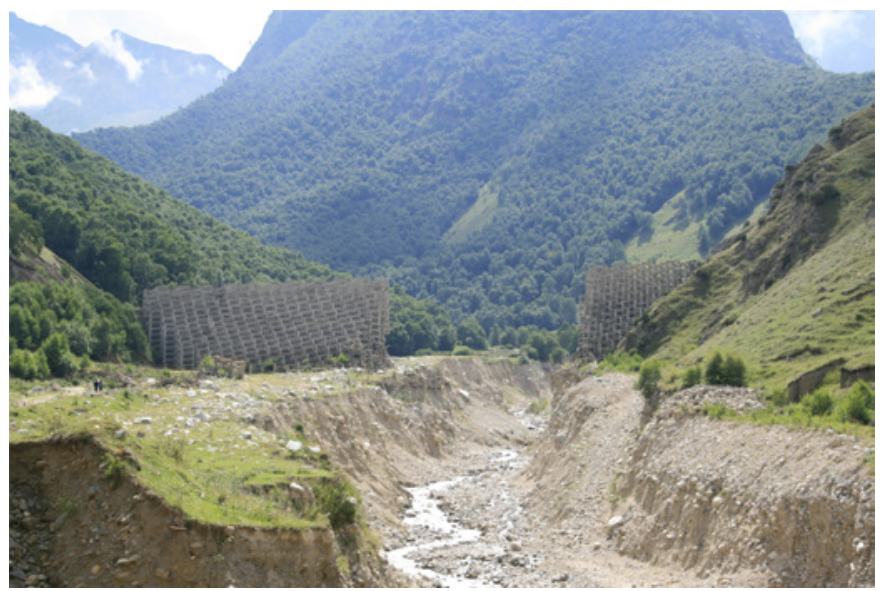

Fig. 2: A structure built for protection of the town of Tyrnyauz on the Gerkhozhan-Suu River was destroyed by a debris flow in 1999.

the Kayarta-Suu. They have been "determined by the processes of reconstruction of modern moraine, formation of periglacial lake potholes, formation and progressive development of fractures and other defects in the moraine body; as potholes of lakes lying in the upper parts of moraines became overfilled, a surface spill over waterretaining barriers and a particular set (sequence) of events took place, which resulted in an inflow of significant volumes of water into debris flow initiation sites and a catastrophic discharge of the accumulated volumes followed by a subsequent debris flow formation; herewith the material of debris flow initiation sites themselves was usually insufficient for formation of a debris flow of finite high density, so the maximum enrichment of the flow took place below, where Upper Quaternary glacial deposits are widely spread" (Zaporozhchenko 2002) or as a result of blockage of the river channel by a large landslide (Buzalgan, March 2011);

- the triggering factors of debris flows reaching the river mouth (except for the 2011 event) have been outbursts of new periglacial lake formations (zones of the Kayarta glacier tongues - eastern, central and western).

2002: The Karmadon tragedy of global proportions: the slide of the Kolka glacier in the Republic of Northern Ossetia - Alania. The actual debris flow occurred only in the lower part of the movement path of water-rock-ice masses: between the Karadon Gates of the Skalny Range and the village of Gizel. About 130 people died. During the 12 years after the tragedy more than 100 papers regarding the event have been published and probably dozens of hypotheses with regard to the causes for the initiation and unusually fast movement of masses in the Genaldon river valley from the Kolka glacier bed to the Skalisty Range $(18.5 \mathrm{~km}, \geq 180 \leq 320 \mathrm{~km} /$ hour $)$ have been set forth, but not one of them has offered conclusive evidence so far. The Sevkavgiprovodhoz institute, which had already been requested to deal with the issues of forecast and protection of people and facilities in connection with the previous glacier advance (surging) in 1969-1970 (Zaporozhchenko and Sinikov 1997), also took part in the assessment of the event and in 
producing forecasts regarding the nearest post-tragedy future in early September 2002. Its specialists were evidently the first to publish their analysis of the situation (Zaporozhchenko 2003a, Zaporozhchenko 2003b) and to this day (2015) they see no reason for changing their views:

- $\quad$ the trigger of the event was a rock-ice fall from the slopes of Dzhimarayhoh mountain onto the Kolka glacier;

- $\quad$ the unusually fast speed of the movement of water-rockice masses cannot be explained by any other causes except for the participation of an "air cushion" in the process;

- a critical condition in the origination site (the cirque of Mayli-Kolka glaciers) for an analogous event in the future may not form before 2020-2025;

- implementation of preventive measures to eliminate the threat of an outburst of a dammed lake near the village of Verhnyaya Saniba was not required (Zaporozhchenko 2006a);

- consequences of the Karmadon debris flow deposits in the Gizeldon river valley for the road and hydraulic engineering infrastructure must be taken into account;

- a significant escalation of threats for the village of Gizel from floods is not forecast for the near-term prospect.

The debris flow in the Gizeldon river valley in September 2002 was a result of a fast descent of mixed masses from the glacial zone of the upper reaches of the Genaldon River. What brings about the cyclic mode of such "slides" (1902, 1969, 2002 within the last 100 years alone)? It would be unjustified to exclude as a possible cause the "warming up" of the magma chamber under Kazbek Mountain as well as related gasdynamic discharges. However there is no acceptable model of a post-trigger movement of masses analogous to the KolkaGenaldon event so far.

2006: On 11 August a debris flow covered inlets of thermal acidulated mineral springs at the Dzhyly-Suu spa near the mouth of the Birdzhaly-Suu River - a right tributary of the Malka River in its upper reaches (Zaporozhchenko 2007). The debris flow reached the springs at $4.00 \mathrm{am}$. Should the event have occurred within the 6.00-22.00 time period, when scores of patients are, there would inevitably have been human losses. There was no place one could have escaped to from the debris flow and the water-rock mass rushing in from the rocky canyon was impetuous. All the structures (buildings, roads, bridges) were destroyed and the baths - covered with deposits. The place where guests gather, whose number grows many-fold in the debris flow hazardous period (July-August), was not protected against debris flow waves or rockfalls. The nature revenged itself on humans for neglecting its laws, though - it should be acknowledged - at the same time it spared its irresponsible users, as it showed some muscles in the short period when there were no people in the baths. Will the necessary conclusions be drawn?

Sevkavgiprovodhoz and MSU (Moscow State University) specialists two weeks before this debris flow disaster had officially warned about the inevitable formation of a debris flow with a potential to reach the spa as a result of the periglacial lake Birdzhaly outburst. There was no timely response to the forecast. In the meantime by the end of July 2006 about 550 thousand cubic meters of water mass behind a glacial riegel (rock-bar) with a less than $1 \mathrm{~m}$ difference in levels between the water surface and the riegel (as of July 20, 2006) had accumulated in Birdzhaly (Verhnee Vostochnoye) lake, lying above the western side of Chungur-Chat-Chiran glacier. The discharge, which started on August 9, 2014, proceeded in surges, as the overspill scarp loosened, during about 2 days. Finally there formed a thin slit in the rock-bar, the water level of the lake lowered by $8-9 \mathrm{~m}$, about $400-450$ thousand cubic meters were released. The debris flow, which reached the Dzhyly-Suu springs, initiated $5 \mathrm{~km}$ above them due to the erosion of the moraine line of an outwash area where a lake had degraded at the beginning of the $20^{\text {th }}$ century, and entrained hard material while moving. The total of transported solid material via the water channel of the Birdzhaly-Suu River on August 9-11, 2006 is estimated at about 100 thousand cubic meters.

While the 2000 debris flow events in the upper reaches of the Kayarta-Suu river were triggered by the discharge (outburst) of a newly formed periglacial lake in the bed, formed by ancient basal moraine material, over the young end moraine crest, the 2006 debris flow on the Birdzhaly-Suu River was triggered by the release (outburst) of the lake, which had a glacial dam and was located on a glacial bed (Zaporozhchenko 2008a).

2007: At 00:15 on August 3 a high density debris flow came up to the outskirts of the south-west part of the village of Bulungu through the Bulungu-Suu River. The underclearance of the bridge over the river channel was almost instantly clogged up by boulders and snag and the debris flow masses moved to the right about $250 \mathrm{~m}$ upstream of the bridge and took a new course through residential buildings and household plots of the village (Fig. 3).

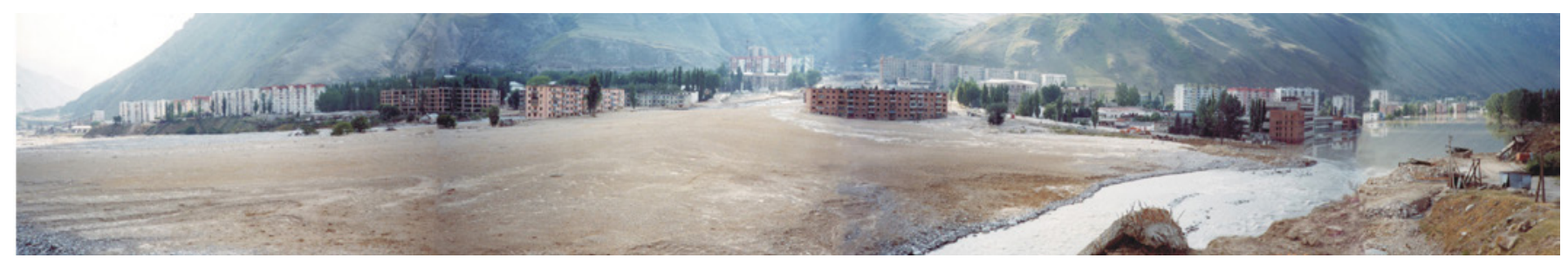

Fig. 3: Consequences of a debris flow of July, 2000 to the town of Tyrnyauz. 
The Bulungu-Suu River rises from the margins of Rakyt and Koru glaciers. The source of the water surge for the debris flow was a location at Zapadny glacier below Rakyt peak at an altitude of 3,650 m, where almost an instant release of a significant volume of water, accumulated in an englacial hollow (hollows), occurred followed by seepage and its buildup.

The 2-3 August 2007 high density debris flow, that came up to the apex of the fan, travelled the $8.5 \mathrm{~km}$ reach from the water discharge site to the bridge over the BulunguSuu River in the village of Bulungu for 1 hour \pm 15 minutes (Zaporozhchenko et al. 2008).

The administration of the region was again informed in an official letter as of 8 October 2002 that the expected "outburst of water from englacial hollows will lead to the formation of a mud-water-ice debris flow. A debris flow of large destructive power and volume may reach the [Bulungu river] mouth... The Bulungu river channel will not be capable to let pass even a sediment-laden flood under the bridge of the autoroad leading to the upper reaches of Chegem. In general the situation on the Bulungu River demands immediate attention from the government" Attention was not paid - the debris flow did take place causing human losses.

In July 2008 another debris flow, having originated in the Bulungu-Suu river basin (on the right tributary of the right branch of the master Rakyt-2 River), reached the village of Bulungu. The triggering surge was the failure of a storm flood dam, created by a landslide-caused motion of solid material at the left border of the mouth of this tributary (Zaporozhchenko and Kamenev 2010).

2010: The above-mentioned village of Bulungu is situated on debris flow fans of the rivers of Bulungu-Suu (its southern outskirts), Sylyk-Suu (central part) and Kam-Suu (northern outskirts). The Bulungu-Suu River originates from glaciers, in the upper reaches of the Sylyk-Suu River there are only rock glaciers while there are no rock glaciers with regard to the Kam-Suu River. But debris flows travel down all those tributaries of the Chegem River: high density mudrock flows on the Bulungu-Suu River, mean-density mud-rock flows on the Sylyk-Suu and water-rock flows on the KamSuu River. In July 1995 a debris flow on the Sylyk-Suu River brought about destruction and deaths in the village of Bulungu (Zaporozhchenko and Kamenev 2011a). A debris flow on 20 July 2010 caused no human loss, because it moved down in daylight time and was preceded by a "warning" roar from the gorge (Zaporozhchenko and Kamenev 2011b). Administrative bodies had been warned of the possibility of the debris flow occurrence at any time in case of heavy precipitation above the debris flow origination sites in the upper reaches, in advance - 8 hours before the event. However village dwellers are hostages to the development of debris flow processes as a consequence of fast growing risks and hazards due to the changing situation, caused in turn by the climatic factor in periglacial and glacial upper reaches of the Chegem river tributaries.

The forecast as of 12.00 July 20, 2010 with regard to the Sylyk-Suu River basin officially stated: "the state of the slope talus in potential debris flow origination sites is so unstable that heavy precipitation won't even be required. Modest humidification will be sufficient to cause 1995-like events. The modern river channel of the Sylyk-Suu is below the apex of the fan and it will not be capable of holding the debris flow within the channel as it passes through the village area, especially because of the [insufficient] underclearance of the bridge of the autoroad leading through the village on to the upper reaches of the Chegem River". The foremost wave of the debris flow on 20 July 2010, as registered on a video tape, reached the fan apex at 20.00. The channel held the incoming masses the first $100 \mathrm{~m}$, but further downstream the debris flow discharge exceeded the capability of the natural channel section, the masses came out of it drifting to the right onto the village, crossed the highway and travelled through buildings and household plots down to the Chegem River. The volume of deposited debris flow material within the village was estimated at 5000 cubic meters (an expert estimate), the peak discharge rate of the debris flow was instrumentally gauged at 190 cubic meters per second.

The 2010 debris flow was caused by heavy precipitation of a storm nature in the upper reaches of the Sylyk-Suu River valley, which had by that time been almost free of snow patches. Four origin sites, located under the western Korgashinlitau range branch at altitudes of about $3,500 \mathrm{~m}$ on the left side of the Sylyk-Suu river valley (Fig. 4), became active. Two western debris flows ( 3 and 4 ) disintegrated, not reaching the flattened part of the valley, two eastern debris flows (1 and 2), although losing part of detritus and some of their energy in the flattened zone (2,900-3,000 m), merged below and steeply entered the canyon-like river channel where again gathered speed and gained momentum, travelled $5 \mathrm{~km}$ via the river and covered a part of the village with debris flow material.

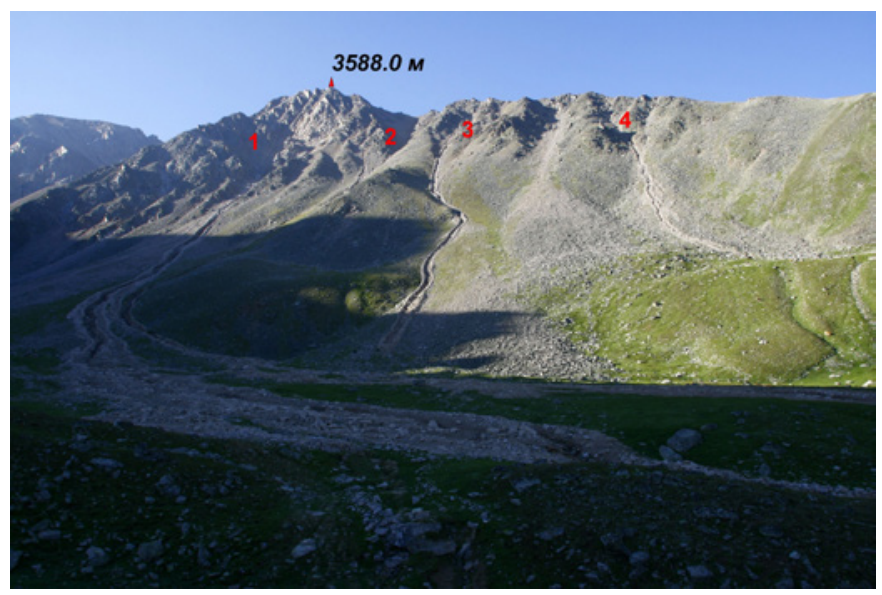

Fig. 4: The sources of the Sylyk-Suu River. 1, 2, 3, and 4 are originating sites of debris flow of July, 20, 2010.

The debris flows had their maximum power when entering the pre-moraine flattened reach of the valley where they formed $5 \times 3 \mathrm{~m}$ grooves and debris flow levees $2-2.5 \mathrm{~m}$ high. It was here where the bulk of suspended sediments and bedloads were deposited. Further down the valley the debris flow continued to deposit the solid component, transported from the upper reaches, including just before the village itself, while also getting slightly enriched with loose, more silt, detritus as it moved. Rains and sequential sudden warming activated the thawing of buried ice and remnants of avalanche snow, situated above the upper reaches of the Sylyk-Suu River valley. An additional concentrated seepage discharge started in 
the lower moraine complex and a glacial grotto with outflowing water opened up in the upper moraine complex causing micro debris flows which took place until the end of July 2010 in diurnal hours, with 20-40 minute intervals.

Debris flows on the Sylyk-Suu River will continue to occur in the foreseeable future. Without engineering channeling thereof into the Chegem River through a channel of clear passage area sufficient for estimated discharges they will again and again go over the settlement causing new destruction and deaths. With regard to the settings of the village of Bulungu, steep gradients of river channels (unlike in case of the Baksan river tributaries near Tyrnyauz) at their junctions with the Chegem River (the last $100 \mathrm{~m}$, the scarp of the high terrace above the flood-plain) are favourable for organising such artificial channeling through debris flow check channels.

The recent debris flow events, natural in their character and disastrous for the village of Bulungu, demonstrate a variety of their causes and of possible initial surges of movement of water masses, capable of reaching the village in a debris flow mode:

the debris flows on the Sylyk-Suu River (1995, 2010) were the result of entrainment of loose single grained formations of the upper reaches by streams, caused by passage of thunderstorm fronts;

the debris flow on the Bulungu-Suu River (2007) was related to the discharge of water masses from englacial hollows;

the debris flow on the Rakyt-2 river (2008) - a BulunguSuu River tributary - was caused by a breach of the landslide dam.

As for the potential debris flow hazard, it lies in the depths of the so called "dead ice" in the upper reaches of the C. Rakyt and Koru rivers (the Bulungu-Suu River basin), whose advance onto the slopes and floor of the valleys (Kamenev and Zaporozhchenko 2013) has been noted since the turn of the $21^{\text {st }}$ century. Moreover, above the village of Bulungu there is a huge landslide massif (up to 1 cubic $\mathrm{km}$ ), moving in a slow frontal translational mode, which can, with its southern flank, block the Bulungu-Suu River at the point of its exit from the gorge.

2011: In July 1983 a mountaineering / ski complex AGLK "Dzhaylyk" was completely destroyed by a debris flow which moved down the Kullumkol-Suu River (the Adyr-Suu River valley, KBR). The fact that the situation in the debris flow site was becoming disastrous for the complex located in the upper reach of the mouth fan had been known.

Early in the morning at the peak of the summer season hundreds of tons of large-size moraine and channel deposits were splashed onto the complex facilities. The complex was destroyed. Fortunately the authors of the debris flow protection design happened to be within that area at that time. Realising that the situation was becoming critical, they had in advance gone up to the foot of Zapadny Tyu-Tyu glacier, where development of the initial stage of the situation had been forecast (the spill over the moraine crest, the outburst of the periglacial lake and the formation of the flood transforming into a high density mud-rock flow). The process started at 5 a.m., at 6 a.m. the water and rock masses, moving in surges, reached the Kullumkol-Suu River channel, at 7 a.m. the first debris flow wave was near the upper borderline of the complex. There already was no-one there, all people had urgently been evacuated between 5 and 6 a.m. at an insistent demand of the specialists, who were witnessing the situation develop near the initiation site of the event with a radio. In total 6 powerful debris flow waves swept down the complex, the last one at 11.39 July 19, 1983 destroying whatever was left of it.

The summer season of 1984 started in a new place in tents, then in felt wagons and, for the $50^{\text {th }}$ anniversary (1988), new permanent infrastructure and a main dormitory block were ready. The sport history of the camp continued up to 1992 , when, with the breakup of the USSR, the relevant ministry ceased being its owner/operator as the time of privatisation came. The mountaineering system, so perfectly organised in the USSR, was becoming a thing of the past. The debris flow fan of the Kullumkol-Suu River - potentially, an extremely dangerous place - became deserted. As time went by the 1983 events started fading from memory.

On 3 August 2011, 28 years after the catastrophic events of 1983, a debris flow went down the Kullumkol-Suu River. (Fig. 5). With regard to its energy and consequences for the fan it was on a par with the 1983 debris flow - the highway

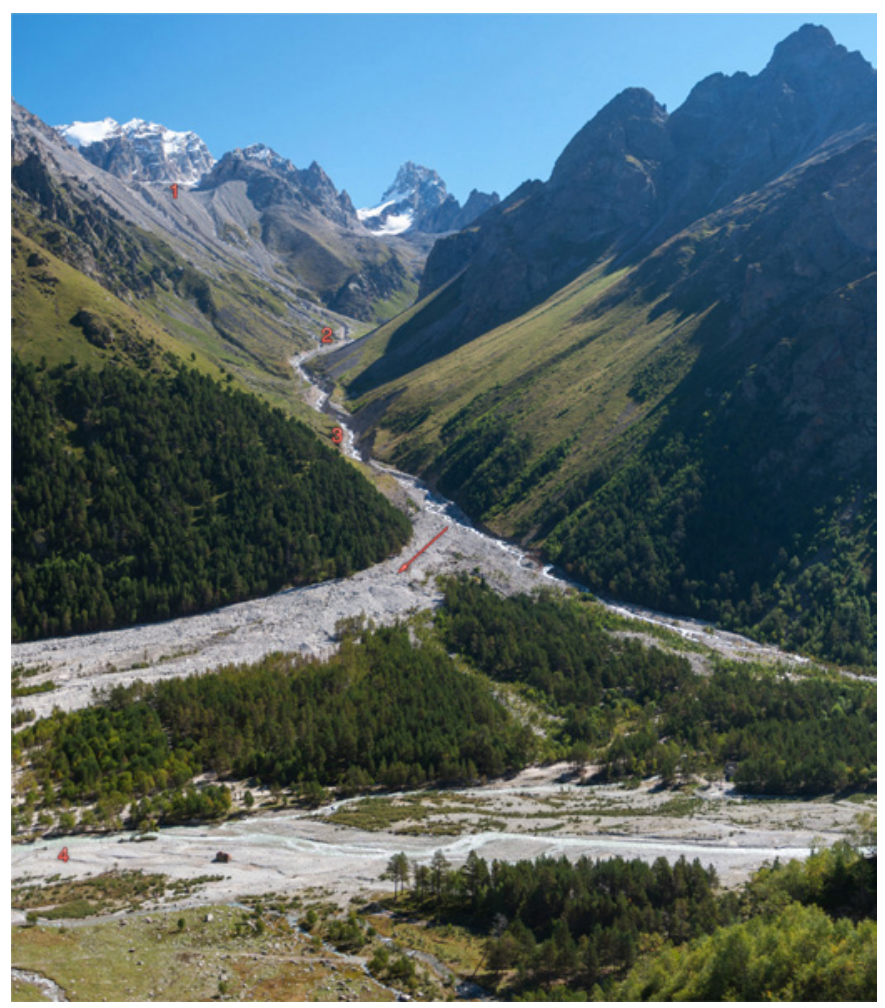

Fig. 5: A view of the fan of the Kullumkol-Suu River on 5 August, 2013 from the left slope of the Adyr-Suu river valley (Photo by V. Kamenev from the survey point chosen by E. Zaporozhchenko in August, 1983). 1 - a debris flow trench of 2011; 2 - debris flow deposits of 1973-2011 on the intermediate fan at the foot of the glacier; 3 - a reach of the channel with the maximum bottom and lateral erosion due to a debris flow on August 3, 2011; 4 - the debris flow receiving river (Adyr-Suu); -> the main direction of deposition of debris flow masses. 
connecting the settlement of Verhniy Baksan and the UlluTau mountaineering base was destroyed and bridge crossings damaged. The main deposition of the rock component took place to the right of the deposition field of 1983, whereas the channel, on the contrary, deviated to the left - the river took a course to the south of the former territory of the "Dzhaylyk" complex (Fig. 5). The site, which had for some time housed a USSR-important tourist, was covered with debris deposits.

The analysis of previous experience (Zaporozhchenko 2005), examinations of areas which have multiply been subjected to the impact of meltwater near the crest of foreground most modern moraines and zones adjacent to the glacier tongue, allow us to give the following assessments of events of the past, present (2011-2014) and future (after 2014):

in the last quarter of the $20^{\text {th }}$ century and at the beginning of the $21^{\text {st }}$ century near the crest of the foreground moraine of Zapadny Tyu-Tyu glacier in summer season (JulyAugust) there formed conditions for a concentrated spill of ablation runoff over the crest followed by formation of debris flow trenches and debris flows, some of which reached the Kullumkol-Suu River mouth (in 1983 and 2011);

- $\quad$ in 2011 the emptying of 2 periglacial water bodies (Fig. 6) at a retreating tongue of a glacier was a triggering mechanism for formation of a trench in the crest and a powerful debris flow;

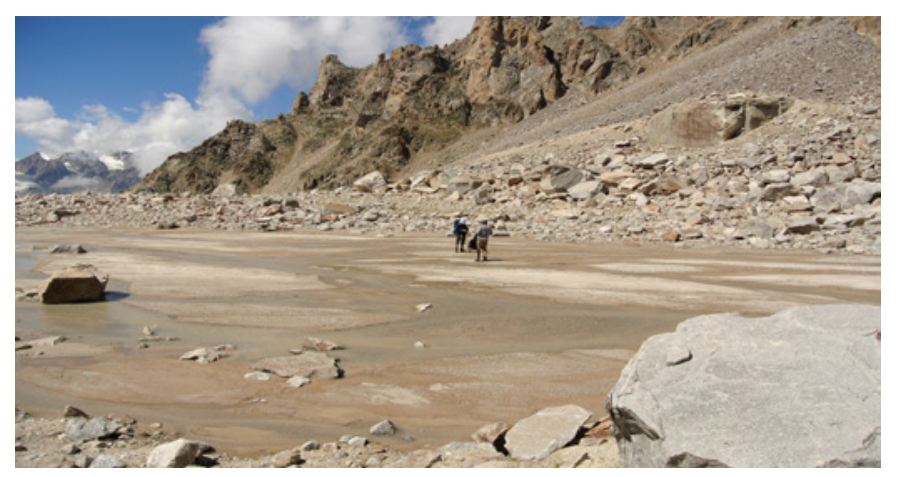

Fig. 6: The bottom of a temporary water body (approx. $3,400 \mathrm{~m}$ asl) at the end of July, 2011, residing approx. 150 $m$ above the platform, adjacent to the moraine crest, near the glacier tongue, which retreated approx. $200 \mathrm{~m}$ in the period of 1983-2013.

after 1983 a concentrated ablation runoff, following terrain features of the surface of the moraine complex freeing itself from ice due to the high rate of degradation of glaciation, migrated in the eastern direction in relation to the crest and accumulated near the edge of the crest, spilling over it and developing a trench (in 1983 the runoff mostly discharged via seepage through loose moraine complex at the crest);

there were no significant accumulations of debris materials along the movement path of the flow down to the existing fan in August 2011; before the damming up, which changed the course of the Kullumkol-Suu River, the depth of the erosion trench in relation to the bank debris levees reached $25 \mathrm{~m}$, on the remaining reach of the river (below the 2011 debris flow trench mouth) the erosion depth did not exceed low single-digit meters (see Fig, 5 for the longitudinal section of the movement path of the 2011 debris flow);

the climatic changes of the last decades are favourable for historically fast restoration of forest vegetation at altitudes of 2000-3000 $\mathrm{m}$ a.s.1.;

a debris flow in the nearest future is expected from an area on the outer slope of moraine between the 2011 trench and the current (2014) area of summer surface overspills (in latter half of the day).

One cannot expect that the debris flow activity on the Kullumkol-Suu River will decrease in the foreseeable future. The findings suggest that there is a growing risk of formation of a new debris flow origination site at the crest of the end moraine of Zapadny Tyu-Tyu glacier followed by a debris flow capable of reaching the apex of the fan and its junction with the Adyr-Suu River (Zaporozhchenko and Kamenev 2014a). This will inevitably happen. The only question is when: will there be a short-term forecast? Such forecasts made on the basis of helicopter flyover inspections and the study of aerial photography and space images alone are usually ill-founded. What is required is regular engineering surveys of debris flow origination sites, but they are not common practice so far.

In July 2011 on the Gyulchi-Suu River, a right tributary of the Cherek Balkarsky River, over the mouth reach of which a diversion canal of the Verhnebalkarskaya Malaya hydroelectric power station is to be built, a powerful high-density debris flow occurred, carrying huge hard rock blocks and completely destroying a highway running through the master valley (Fig. 7).

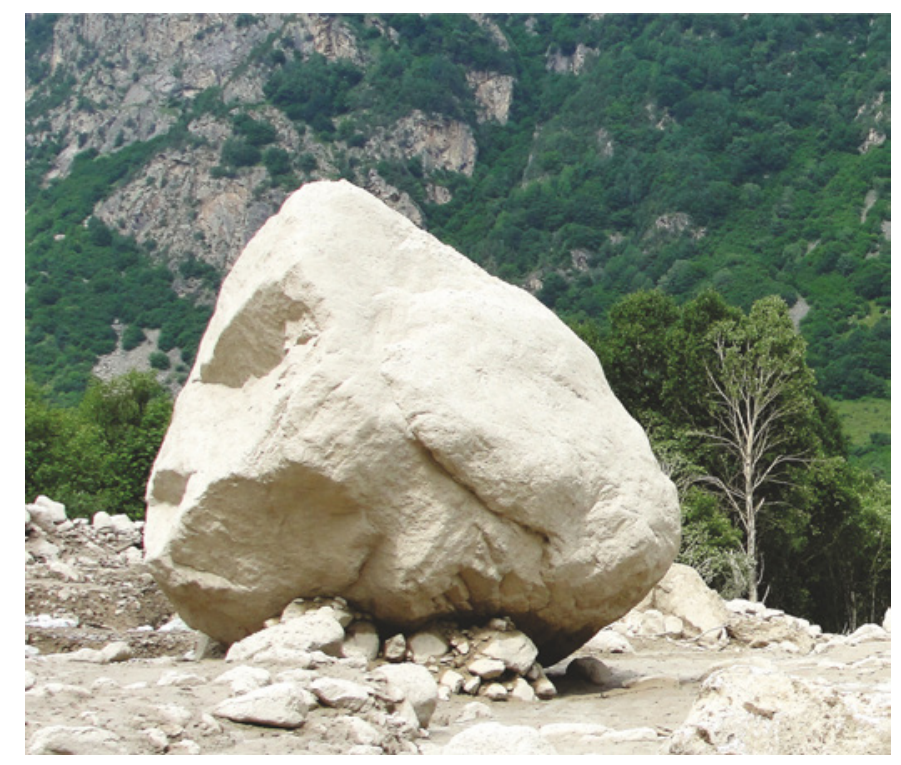

Fig. 7: A debris flow on the Gyulchi-Suu River (a right tributary of the Terek Balkarsky River) on July 16, 2011 carried granite blocks of up to $60 \mathrm{t}$.

Unfortunately the causes of this debris flow, conditions of its formation and transit remained unexplored. 
2012: The whole 2012 a dramatic worsening of organoleptic properties of water was registered downstream the village of Guzeripl in the Belaya ("White") river (Republic of Adygea), which earlier had completely been in accordance with its name. It manifested in high turbidity of the stream, which made it impossible to use the water in the wellestablished centralized structure of water supply to populated localities throughout the whole river valley. A critical situation was developing.

The terrain in the basin of the upper reaches of the Belaya river (upstream the village of Guzeripl) is rough desolate forest country. Interpretation of space images did not give an unambiguous picture of what was going on.

In the latter half of December 2011 (a more precise date cannot be established, but most probably in the last week of the month) in the upper cirque of the $2^{\text {nd }}$ left tributary of the Armyanka River - the Mutny Teplyak River - a virtually instant landslide-mode motion of a large mass of clay slate of the Toarcian stage of the Jurassic period and its derivatives from southern and western direction slopes occurred, completely blocking the tributary valley (Zaporozhchenko and Kamenev 2014b). Prior to that there was a continuous development of landslides of various generations, including modern, $\leq 10 \mathrm{~m}$ thick, in the middle and upper parts of the valley (as well as in a neighbouring valley of the $1^{\text {st }}$ left tributary); throughout the area there commonly were small lakes in pits of landslide moulds and levees, whereas landslide deposits were saturated with groundwater.

The blocking of the valley by the 2011 landslide led to the formation of ephemeral water bodies upstream of the blockage which were fed by runoff from superposed slopes. As the landslide massif had initially had high humidity and been loosened in its surface part, the new lake formations soon started outbursting giving rise to debris flow nature processes (the entrainment of water-saturated rocks resulted in mud-rock flows).

The material of those flows starting from 2011 and during the whole 2012 was deposited within the river and at the lower parts of slopes down to its confluence with the Mutny Teplyak River and then on along the latter over a distance of about 2 $\mathrm{km}$, washed over by surface water of the river (Fig. 8).

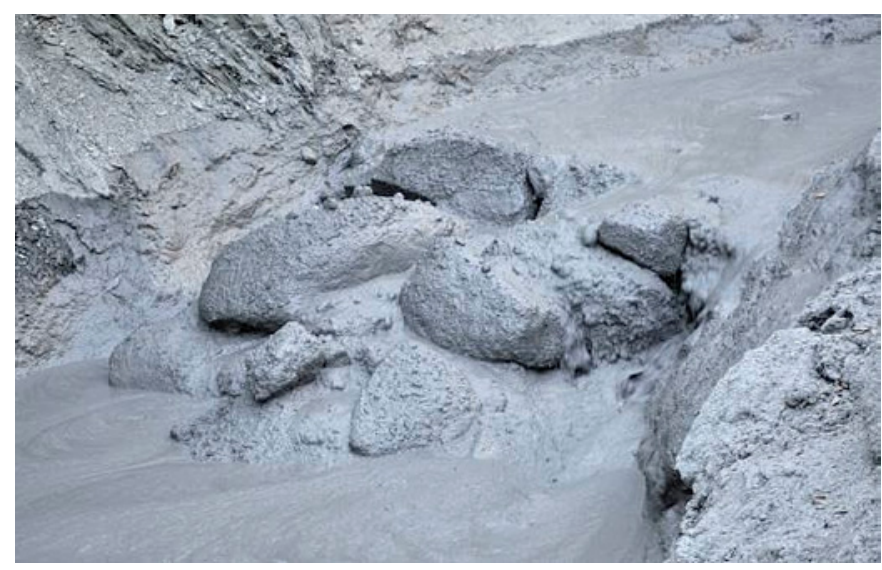

Fig. 8: At 17:00 on September 5, 2012. 17.00, a mud rock flow occurred within the channel below the rocky tributary of the Mutny Teplyak River.
Moreover the mud component, consisting mainly of slate (and argillites) easily disintegrated into fine fractions, conditioned the stability and long-life of the suspended shaly matter in the river water.

By the beginning of September 2012 in the upper reaches of the $2^{\text {nd }}$ left tributary of the Mutny Teplyak river about 1.52 million cubic meters of slid material had accumulated and no less than 500 thousand cubic meters of secondary deposits had collected in the channel of this tributary and that of the Mutny Teplyak. Landslide processes after the peak of their activity continued to develop and occurred at slopes above the break-away walls of the main deformation outline of 2011, but on a significantly lesser scale. Nonetheless registered ground surface ruptures (as of 6-7 September 2012) are indicative of the possibility of further replenishment of the landslide of 2011-2012 with similar masses up to 500 thousand cubic meters in volume.

The liquefied landslide accumulations of previous generations throughout the channel of the $2^{\text {nd }}$ left tributary of the Mutny Teplyak River moved in a surging mode of a mudrock flow. Conditions for such a mode, such as damming, [from time to time] arose at the entrance to the rocky canyon, located 500-700 $\mathrm{m}$ away from the tributary mouth; with continued negative temperatures, as was the case from late January to early March 2012, the process of transportation of material downstream ceased and the river water then became clear for a short period of time.

The liquefied state of the landslide body, the blockage by it of the valley and relatively warm days at the beginning of winter 2011 and the substantial grade of the transporting channel led to the initiation and development of a debris flow process, which continued in a surging mode the whole of 2012 (the water component being surface, ground and spring waters as well as atmospheric precipitation).

The composition of the washed out fine-grained part of debris flow deposits of 2011-2012 contributed to transformation of fine and sedimentation-resistant clay fractions, retained by the water stream for a protracted period of time and at a long distance, into suspended matter, thereby rendering these streams unsuited with regard to their organoleptic properties for direct (or via the existing system of stabilization ponds) use in the potable water supply system. The settling suspended matter colmataged single-grained easily permeable alluvial deposits of the river channels and floodplains and it had an effect on the productive capacity of bore-hole water intakes.

The actual development of debris flow events in the summer of 2012 in the basin of the Baddon river - a tributary of the Ardon River (RNO - Alania) demonstrated that even in parts of basins of third-order tributaries (Urusti and Tsaduti rivers, the Baddon river tributaries) scenarios of initiation, development and disintegration of debris flows of the same time period of favourable hydrometeorological factors significantly vary (Zaporozhchenko et al. 2014).

2014: The activation of manifestations of debris flow events of various nature on the northern slope of the Caucasus Range in the overwhelming majority of previously known cases occur in late July to late August, with disastrous events taking place exclusively in July-August. But 2014 was something of a surprise. The peak of rains occurred on 20-21 May when rains 
of a stormy nature were over the whole of Severo-Yurskaya (Northern Jurassic) depression between the Skalisty and Bokovoy ridges. On the tributaries of the main rivers Cherek, Chegem and Baksan that cross this depression there occurred large-scale landslide processes transforming into debris flow processes which led to disastrous consequences. An emergency situation was declared. There were fatal casualties. The river channels, on which debris flows had before either had limited development without exiting onto main valleys or not been historically recorded at all, operated in debris flow modes.

Severo-Yurskaya depression is known as a "rain shade" zone, so the situation of May 2014 was completely unexpected. Rain precipitation over the depression's steep slopes, formed by clay-slate and argillites of the Jurassic period, occurred at elevations of 250-2,700 $\mathrm{m}$ asl. At higher altitudes in the solid hard rock area it was snowing and the snow did not provide the required amount of the water component so not a single one of known debris flow origination sites was triggered. In the Baksan river valley the settlement of Bylym as well as a road connecting the settlements along the Baksan and Chegem rivers and a road along the Gestanty River were damaged whereas the huge Tyrnyauz tailings storage facility on the Gizhgit River was on the brink of a critical situation.

The Gizhgit River is confined to a tunnel directing its natural stream flow around the tailings storage. The tunnel has a design discharge rate of $\leq 65$ cumecs. In summer 2002 the discharge of the debris flow-like flood before the entrance portal of the tunnel at peaks reached 110-130 cumecs, the tunnel was not capable of passing the flow so the water started filling the residual capacity of the tailings pond. It was a matter of hours before a disaster - the washout of retaining embankments - could potentially take place (Zaporozhchenko 2004). The construction of an open diversion canal for passing the flow of the Gizhgit River with a $0.1 \%$ occurrence probability discharge rate of 270 cumecs started immediately. Soon, however, the construction stopped and has not been resumed since. The 2014 events aggravated the situation, which had already worsened, with regard to passage of flood waves, after 2002.

Upstream from the tunnel a flood of varying characteristics - from a dense water flow to a water-rock flow with a peak rate of 63.2 cumecs (the mean of 3 sections instrumentally gauged) - occurred. Debris flow deposits of 2002 were transported through the tunnel, the channel bed deepened by several metres. Washout of the existing left-side brink of the embankment occurred with its relocation to the slopes $50 \mathrm{~m}$ away thereby forming vertical walls up to $8 \mathrm{~m}$ high close to the entrance portal, followed by a scour and partial collapse of the reinforced concrete structure of the portal (Fig. 9).

Should another one or two similar floods take place, the river will breach the dam (which already suffered in 2002), that diverts the Gizhgit River into the tunnel, take the latter "out of business" and bring about unpredictable consequences both for the tailings storage, which contains water-saturated fine-dispersed masses of toxic concentrate products, and for the Baksan River, over which the facility is situated.

At the same time period on the opposite slope of the Baksan river valley, on its right tributary - the Gestanty River - and its third-order right tributaries, powerful debris flows occurred. On 21 May of 2014 a mud flow originated from the gorge of the Kerdeuk River (first right tributary of the Gestanty River) and road culverts were not able to let it through. Allotment gardens were covered, a number of outbuildings of the settlement were damaged (Fig. 10). The debris flow had a wave-like behaviour and a discharge rate of up to 50 cumecs. The waves were about $2 \mathrm{~m}$ high above the edges of the natural channel. The peculiarity of the situation lay in the fact that before the settlement the river is wedged between rocky gates. Should there be barriers on this river, which has irregular configuration in plan and a $40 \mathrm{sq} \mathrm{m}$ section, a flow moving through the gates might take a course either to the left or to the right of the movement path of the 21 May 2014 debris flow and thus go straight onto residential buildings.

On 21 May 2014 water-rock flows also went down the Gestanty river channel while mud-rock flows - down the rest

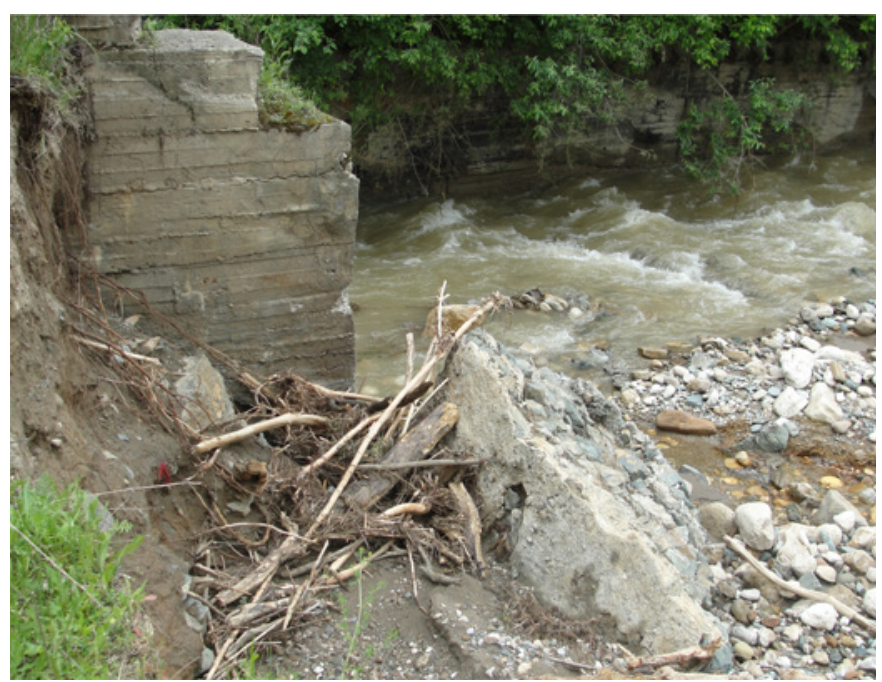

Fig. 9: Washout of the upstream slope and destruction of a part of a reinforced concrete structure of the entry portal of the tunnel on the Gizhgit River as a result of a debris flow of May 21, 2014.

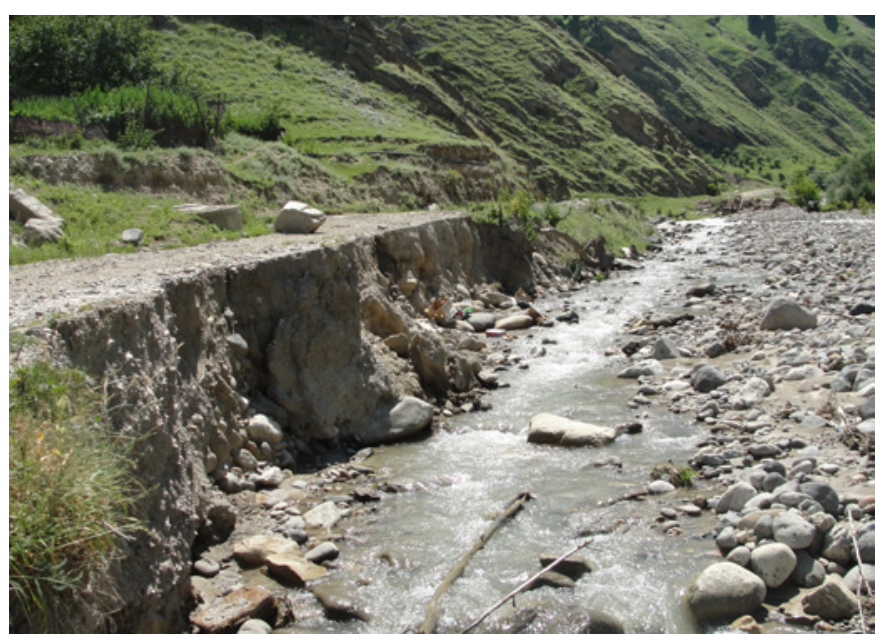

Fig. 10: Lateral erosion of the right bank of the Gestanty River as a result of a water rock flow on May, 21, 2014; a road to the potable water intake for the settlement of Bylym was destroyed. 
of the right-bank tributaries (above the Kerdeuk river mouth). Some stretches of a highway were damaged, potable water supply of the settlement of Bylym was disrupted (due to the damage to a water intake at the Zydagit River). All those debris flow events were consequences of the developed situation, whereby multiple landslide collapses of $\leq 2 \mathrm{~m}$ thick watersaturated surface masses of soil, clayed rubble colluvium and upper eluvium of Yurassic slate developed on slopes of second- and third-order valleys. Those landslide collapses then transformed into landslide flows. The shifted material either stopped in pits of ancient landslide slope surfaces of terrain flattening areas or ended in ravine bottoms, thus creating conditions for the initial accumulation. The enrichment took place within channels of perennial streams where there was sufficient clayed and rubble-boulder material for water flows to transform into water-rock, mud and mud-rock flows.

The events on the Chegem River developed in an analogous way, only with larger-scale manifestations and more disastrous consequences for the infrastructure.

Mud-rock flows from many right tributaries of the Chegem River on 21 May 2014 reached their mouths. The most powerful ones (on the rivers of Abardan-Suu and BykmylgySuu) not only destroyed the gas main pipeline (the gas supply was disrupted for a month) and a road between the plain and mountainous parts of the Republic in the Chegem river valley, but also blocked this transit river, brought about a dangerous change in the channel profile and blocked the underclearance of a single bridge in miles (Fig. 11).

Unlike the debris flows that reached the mouth parts on the rivers of Abardan and Bykmylgy-Suu (as well as the rivers

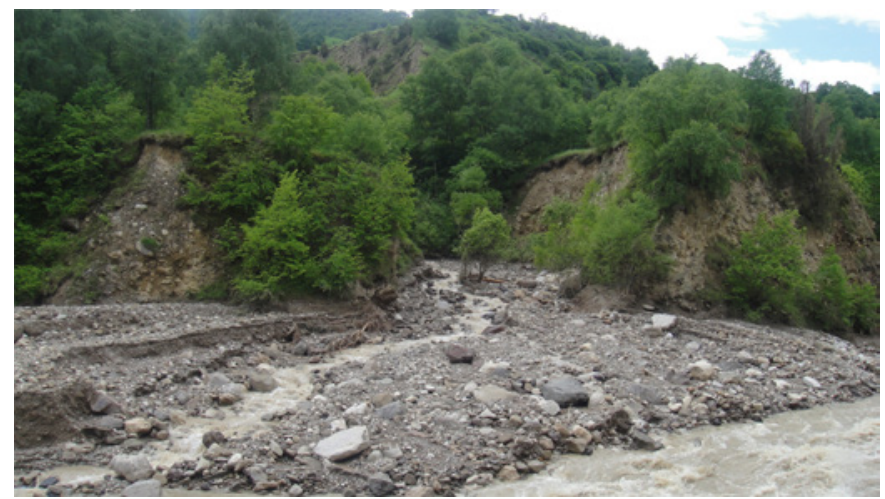

Fig. 11: A debris flow fan of the Abardan-Suu River blocked the Chegem River on May, 21, 2014 and destroyed a gas pipeline and a section of the Nizhny Chegem-El Tyube highway.

of Zhylgy-Suu and Tuzulgu-Suu) and were categorized as mud-rock flows, simultaneous debris flows below (to the north of) the settlements of El-Tyubyu and Bulungu on the rivers of Kardan and Kam-Suu were water-rock flows.

The Kardan-Suu River flows into the Chegem River at right angle. It feeds on springs (the main accumulation horizon is Lower Cretaceous fissured limestone, the confining bed - Malm clay rock). The debris deposits carried by the river blocked the transporting river for 5-10 minutes. The subsequent breaching of the formed dam led to the undercutting of the 30$40 \mathrm{~m}$ high Chegem valley left-bank side, formed by singlegrained proluvial material with clayey joining material.

The upper reaches of the Kam-Suu are situated within the Bokovoy ridge and are fed by springs from moraine complexes. In the mouth part the river runs through the northeast outskirts of the village of Bulungu. Adjacent to the right bank of the river is the site allocated for residential buildings and household outbuildings of a new housing development "Kam", some of which are already being built by plot owners despite the fact that the area is not protected against the impact of water-rock debris flows (the old village of Kam was situated in a safe location), despite the fact that rainfall floods and water-rock debris flows come down the river fairly regularly. They cannot pass through the culvert under the autoroad and thus create problems as once again was the case in May 2014.

Changes to the trajectory of the flow of the KardanSuu river water into the Chegem river have to be made and engineering protection of the "Kam" housing development and adjacent left-bank plots of the settlement of Bulungu has to be organised (the replacement of the piped crossing with a bridge with underclearance properties based on the estimated flow rate, the engineering management of the mouth transit).

The debris flow risk for the population of the upper reaches of the Chegem River valley had grown.

But the most catastrophic debris flow event for the North-Caucasus region in 2014 occurred on May 17, when icerock masses blocked the Terek river channel in Daryal gorge, situated on the border between North Ossetia and Georgia: the auto traffic on the Voenno-Gruzinskaya (Military Georgian) Road was disrupted for a month, the "Russia - Transcaucasia" gas supply main was ruptured, an interstate electric power line was destroyed, and there were human losses. In some respects this event was analogous to the Kolkinsky "avalanche" in 2002. The fall of ice-rock masses from the eastern slope of Kazbek mountain in the accumulation area of Devdorak glacier from a height of 4,400-4,500 m (Fig. 12) onto the flattened tongue of this glacier caused the formation of an avalanche-like highspeed flow (Vmax $>200<300 \mathrm{~km} /$ hour), which rushed down the valley of Amalishka and Kabahi rivers.

Having entered the Terek valley, the flow ran into the right-bank of the gorge, turned left, forming a blockage 1-1.5

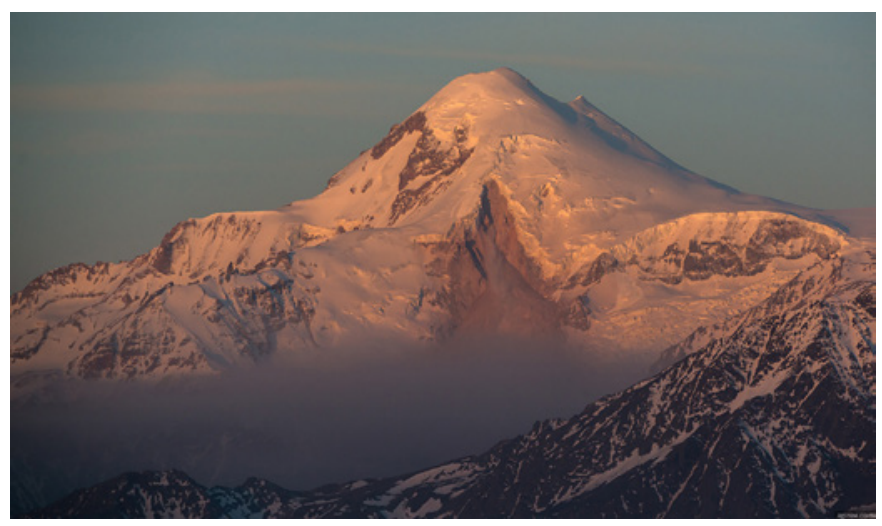

Fig. 12: View of the part of the eastern slope of Kazbek Mountain immediately after the catastrophic event (18 May). Photo by T. Agirov. 
million cubic meters in volume and a dammed up water body. Fortunately the spill over the blockage dam started soon (unlike in a situation on the Genaldon river near the village of Gornaya Saniba in 2002), and the backwater effect was deterred by the "self-switching" of the Terek river's artificial channel (a diversion tunnel of the Daryal hydro-electric power station (Fig. 13)), constructed before the disaster, into operation.

The blockages of the Terek River by large debris flows on the left-bank tributaries, nourished by Kazbek glaciers on the

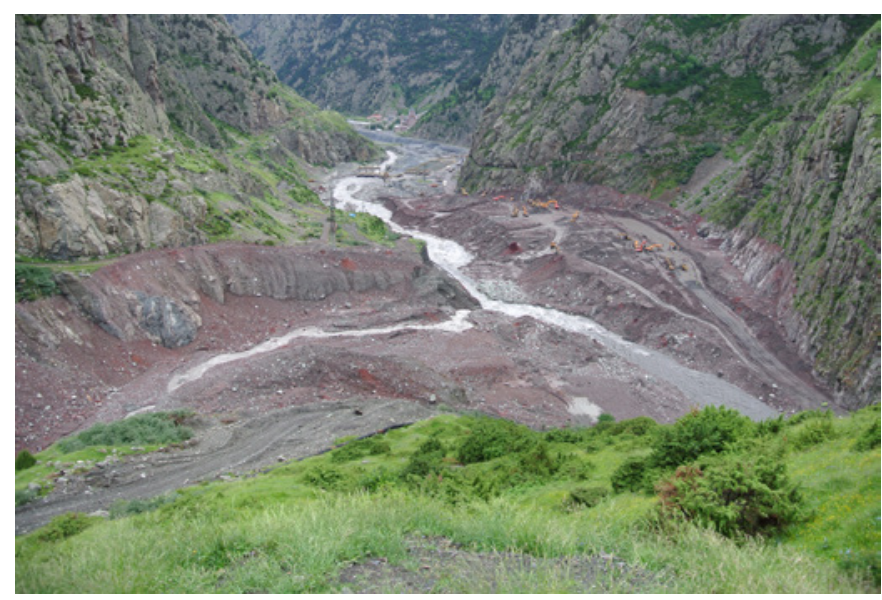

Fig. 13: The Terek River with the Daryal hydro-electric power station under construction in the distant view on June 10, 2014. Breaching of the debris rock-ice flow deposits of the Kabahi River.

territory of Georgia, had taken place before (Zaporozhchenko and Chernomorets 2004). Surveys immediately after the disaster and in early June 2014, the results of which were published by Chernomorets (2014), and Tavasiyev and Galushkin (2014) were unable to provide information that would make it possible to characterise the events with sufficient scientific substantiation and carry out a cause-and-effect analysis.

\section{CONCLUSIONS}

1. The Caucasus region as well as other mountain systems on Earth currently undergoes a cycle of the increase in frequency of debris flows, caused by gravitational forces, and in the power they manifest. Such events are related to the reaction of steep mountain areas and piedmont areas to the changes in the climatic conditions.

2. The overwhelming majority of scientific forecasts informs the public of and prepares it for the continuation of this trend in the nearest decades.

3. Examples of real debris flows indicate an extreme variety and individuality of triggering causes, conditions for initiation, formation and discharge not only in debris flow hazardous tributary basins (catchments) of major transporting arteries as a whole, i.e. tributaries along which debris flows travel down in the vast majority of cases, but also in areas of upper third-order catchment valleys and even their parts. It is therefore unjustified to expect a single model suitable for calculating all gravitational processes.

4. When there are no fixed stationary observations of debris flow processes, of properties and settings, determining behavioral peculiarities and character of debris flows, on the one hand, and when the possibilities of remote observations for short-term debris flow danger forecasts without the knowledge of a concrete field situation are overestimated, on the other, a lot depends, as in other fields of human activities, on the professional engineering level of those, who assess debris flow risks and parameters of the processes and also on the timeliness of danger warning. Forecasts by experts, as practice shows, may well be of acceptable accuracy.

5. The nature (with its acts including debris flows) is more powerful that the mankind with its current capabilities. We have to come to terms with it. Thus debris flow mitigation structures should be based on the principle of maximally ensuring the passage of expected (estimated) debris flows through existing (natural) or artificial channels into natural transporting first-order watercourses (for the North Caucasus these are the Cherek, Chegem, Baksan, Malka, Ardon, Belaya rivers, etc.).

6. The studying of debris flow threats, destabilising the modern civilisation, must become a paramount task of research and should result in adequate engineering protection measures.

\section{REFERENCES}

Botavin, D. V., Tutubalina, O. V., Zimin, M. V., and Eremkina, P.G., 2013, Geoportal of MSU: regional projects. Earth from Space. v. 16, p. 56 (in Russian)

Bushueva, I. S., 2013, Fluctuations of glaciers in Central and Western Caucasus on the basis of catastrophic, historical and bioindicational data of the last 200 years. Ph.D. thesis in Geography. Moscow (in Russian)

Chernomorets, S. S., 2014, The new "Kazbek blockage" of 17 May 2014. Nature, no. 7, pp. 67-72 (in Russian)

Kamenev, N. S., and Zaporozhchenko, E. V., 2013, Debris flow processes in North Caucasus: formation conditions, forecast problems. Proc. Int. Conf. and workshop for young scientists and post-graduate students "First Vinogradov readings. The future of hydrology". SPb: SPbGU, pp. 62-64 (in Russian)

Kazakov, N. A., 2014, Technogenic debris flows in Krasnaya Polyana. Proc. III Int. Conf. "Debris Flows: disasters, risk, forecast, protection". Yuzhno-Sahalinsk, pp. 198201 (in Russian)

Kolka glacier: yesterday, today, tomorrow, 2014, Associate Editors: members of the Academy of Sciences - Mokov, Yu. G., and Zaalishvili, V. B. Geophysical studies centre of Vladikavkaz research centre of Academy of Sciences of Russia in the Republic of North Ossetia - Alania. Vladikavkaz. 432 p. (in Russian) 
Oerlemans, J., 2001, Glaciers and climate change. Lisae: A. A. Balkema Publishers, 148 p.

Report on the research paper "Study and assessment of the impact of anthropogenic influence and exogenetic processes (floods, debris flow, avalanches), water pollution of the Terek river catchment, and development of recommendations aimed at prevention of adverse effects of the waters and improvement of their qualitative composition", 2014, in 6 parts (editor and scientific supervisor: Zaporozhchenko, E.V.). State contract No. I-12-72. OAO "Sevkavgiprovodhoz", Pyatigorsk, 1366 p.; illustrated (in Russian)

Tavasiyev, R. A., and Galushkin, I. V., 2014, Rock-Ice fall from Kazbek Mountain on 17 May 2014. Bull. Vladikavkaz Res. Centre. v. 14(2), pp. 43-45 (in Russian)

Zaporozhchenko, E. V., 1985, An unusual debris flow on the Kullumkol-Suu river. Meteorology and hydrology, v. 12, pp. 102-108 (in Russian)

Zaporozhchenko, E. V., 1988, The story of destruction and reconstruction of the "Dzhaylyk" mountaineering camp through the eyes of and as documented by a geological engineer. Collection of research papers of OAO "Sevkavgiprovodhoz". Pyatigorsk. Issue 13, pp. 89-117 (in Russian)

Zaporozhchenko, E. V., 2001, A debris flow of rare recurrence in the Gerhozhan-Su river catchment and protection solutions for the town of Tyrnyauz (KBR). Proc. Int. Conf. "Geotechnology. Assessment of the state of foundations and structures". St. Petersburg. Vol. II, pp. 53-60 (in Russian)

Zaporozhchenko, E. V., 2002, Debris flows in the Gerhozhan-Su river basin: manifestation history, formation conditions, energetic characteristics. Collection of research papers. Pyatigorsk: OAO "Sevkavgiprovodhoz". v. 15, pp. 80148 (in Russian)

Zaporozhchenko, E. V., 2003a, Genaldon glacial disaster of 2002. Irrigation and water works, v. 1, pp. 2-6 (in Russian)

Zaporozhchenko, E. V., 2003b, Kolka glacier and the Genaldon river valley: yesterday, today, tomorrow. Collection of research papers of OAO "Sevkavgiprovodhoz". Pyatigorsk. v. 16, pp. 15-35 (in Russian)

Zaporozhchenko, E. V., 2004, The Gizhgit River as a source of flooding and debris flow hazards for the structures of the Tyrnyauz mining and concentrating works (TMCW). Issues of effectiveness enhancement in construction. Nalchik. v. 2, pp. 159-169 (in Russian)

Zaporozhchenko, E. V., 2005, Debris flows on the northern slope of Central Caucasus: assessment of danger and characteristics, engineering protection principles. Makkaveev readings - 2004. Science editor: Chalov, R.S. Moscow, pp. 26-35 (in Russian)

Zaporozhchenko, E. V., 2006a, In the Genaldon and Gizel'don river valleys. 2004. Prevention of dangerous situations in high mountain regions. Vladikavkaz: "Olimp" Publishing, pp. 118-123 (in Russian)
Zaporozhchenko, E. V., 2006b, Changes in flood discharge conditions in the Genaldon and Gizel'don rivers after the Kolka events of September 2002 in the Republic of Northern Ossetia - Alaniya. Proc. VI AllRussia hydrological convention. Section 2. Moscow: Meteorological Agency of the Rosgidromet (Federal Service of Russia on Hydrometeorology and Monitoring of the Environment). 2006, pp. 277-280 (in Russian)

Zaporozhchenko, E. V., 2007, Debris flow problems in the upper reaches of the Malka River. Proc. VI Int. Conf. "Innovative technology for sustainable development of mountain areas". Vladikavkaz, pp. 228-229 (in Russian)

Zaporozhchenko, E. V., 2008a, Degradation of mountain glaciation in the Caucasus region of Russia as an activation factor of debris flow processes of glacial genesis. Proc. Int. Conf. "Debris Flows: disasters, risk, forecast, protection". Pyatigorsk, pp. 106-109 (in Russian)

Zaporozhchenko, E. V., 2008b, Debris flows on the KaraKaya-Su and Birdzhaly-Su rivers in Kabardino-Balkaria: comparative analysis of the past and contemporary history. Bull. of the Vladikavkaz Res. Centre, v. 8(1), pp. 33-43 (in Russian)

Zaporozhchenko, E. V., and Chernomorets S. S. 2004, The history and state of exploration of Kazbek debris. "Nasledie", collection of articles. Pyatigorsk: Caucasus Mountain Soc. v. 5, pp. 33-54 (in Russian)

Zaporozhchenko, E. V., and Kamenev, N.S., 2010, The recent history and forecast of disastrous debris flow processes in Northern Caucasus. Geomorphological processes and their practical aspects. VI Shchukin readings. Proc. Moscow, pp. 111-112 (in Russian)

Zaporozhchenko, E. V., and Kamenev, N. S., 2011a, Catastrophic events in the Bulungu river area (KBR): description of peculiarities and development tendencies of debris flow processes. Sustainable development of mountain areas, v. 1(7), pp. 27-38 (in Russian)

Zaporozhchenko, E. V., and Kamenev, N. S., 2011b, Debris flow of 20 July 2010 on the Sylyk-Suu River. Irrigation and water works, v. 5, pp. 6-9 (in Russian)

Zaporozhchenko, E. V., and Kamenev, N. S., 2014a, The Kullumkol-Suu river valley: 21st century. Collection of research papers of OAO "Sevkavgiprovodhoz". Pyatigorsk. v. 20, pp. 103-116 (in Russian)

Zaporozhchenko, E. V., and Kamenev, N. S., 2014b, Natural event in the upper reaches of the Belaya river basin (Republic of Adygeya). Collection of research papers of OAO "Sevkavgiprovodhoz". Pyatigorsk. v. 20, pp. 117134 (in Russian)

Zaporozhchenko, E. V., and Sinikov V. A., 1997, Protective measures, caused by the advance of Kolka Glacier, in the Gizel'don river valley. Collection of research papers on engineering protection against dangerous geological processes. Pyatigorsk: OAO "Sevkavgiprovodhoz". v. 12, pp. 48-52 (in Russian) 


\section{E. V. Zaporozhchenko}

Zaporozhchenko, E. V., Kamenev, N. S., and Nikulin, A. S., 2014, Local peculiarities of debris flow formation settings in the valleys of the Caucasus Ridge as exemplified by the Baddon river catchment (Republic of Northern Ossetia - Alaniya). Collection of research papers of OAO

"Sevkavgiprovodhoz". Pyatigorsk. v. 20, pp. 135-157 (in Russian) 